\title{
The Role of Metropolitan Areas in the Territorial Development and the Increase of the Quality of Life
}

\author{
Alina Florentina SARACU ${ }^{\star}$, Nicolae Viorel TRIF ${ }^{\star \star}$, Adelina PRICOPE ${ }^{\star \star \star}$ \\ A R T I C L E I N F O \\ Article history: \\ Accepted December 2019 \\ Available online December 2019 \\ JEL Classification \\ I 31, 018, 029, R58, R59 \\ Keywords: \\ Metropolitan areas, Poverty risk, \\ Urbanization, Suburbs, \\ Suburbanization

\begin{abstract}
A B S T R A C T
Metropolis process plays a major role in the development of European space, a process in which metropolises have become engines of growth and main nodal points of innovation, in the sense that the economies created by the metropolises and the benefits of the activities carried out at their level are propagated to a smaller urban centers from every country. Because there are fundamental differences between the way heavily urbanized and deeply rural regions are managed, between major metropolises and small and medium-sized cities, between territories with barriers and obstacles to development and the more uniform territories, generally without obstacles, there can be no universally valid policies. Policies must be adapted to the specificity of the place where they are applied, in order to capitalize on their endogenous and territorial potential.
\end{abstract}

(C) 2019 EAI. All rights reserved.

\section{Introduction}

The concept of metropolitan area was first implemented in the U.S. in the 1950s under the form of "Standard Metropolitan Statistical Areas" (SMSA) and subsequently taken over by other Anglo-Saxon countries. The criteria for identifying and defining an SMSA are based on the structure of the active population and on the phenomenon of polarization and periodic migration.

In New England, the delimitation is even more rigorous as instead of the administrative perimeter of the counties, the urban territory is used as a starting point for delimitation. In France the term "industrialurban population area" (ZPIU) is used so as to include urban and rural administrative units where the level of daily home-work migration is relatively high.

Understanding metropolises as complex territories organized functionally, spatially and institutionally, having significant social, economic and ecological impacts at different spatial scales, represents an essential premise in terms of urbanistic theories, but also from the perspective of the implications for the development of these areas. [21]

The definition of the metropolitan term synthesized in the thematic study Espon [44] starts from its understanding from the point of view of the urban structure as a whole group of cities. The specifications, however, relate aspects of size to the problem of accessibility and in addition to the need for economic diversity and the existence of a particular quality human environment. This range of qualities is materialized in a series of criteria, so as to allow the classification of urban agglomerations in the category of metropolis.

The conditions under which these definitions are made require the unanimous adoption of the concept of polycentricity, which has led to six main criteria for quantifying the European importance of urban agglomerations, which ultimately can hierarchize the potential of each on a global scale: transport, tourism, industry, knowledge, decision and administration. [7]

The metropolitan areas, as structures of inter-communes cooperation, result from the potential complementarity of the two types of administrative structures at local level: those of an advanced degree of urbanization, represented by nuclei of regional and departmental convergence (characterized by the highest population densities at the city level and through the administrative territories restricted in size, also having the largest local budgets) and the communes, included in their peri-urban area, with limited financial resources but having spaces in excess. The high price of the land in the city determines the phenomenon of exurbanization, by locating investments related to the city in its peri-urban area, the administrative boundaries becoming purely formal, and the city extending beyond its administrative limits, while the rural one evolves from polarized space to an integrated space. [22] The inter-communal cooperation at the level of the peri-urban area thus becomes essential for an integrated regional development. 


\section{European metropolitan areas}

About 212 million people, i.e. 29\% of Europe's total population, live in the 500 major cities of the continent. The population of Europe is estimated at 727 million inhabitants, with 379 million inhabitants in the European Union, before its expansion in 2004. [18] The percentage of people living in big cities, i.e. those with a population of over 150,000 inhabitants, varies considerably from one country to another. Out of the largest countries in Europe, France has the smallest number of inhabitants in large cities. Only $10.4 \%$ of the French men and women live in the larger cities of the country. Russia has one of the highest figures: about $42 \%$ of the inhabitants are residents of large cities. The countries that belonged to the former Soviet Union show similar high percentage figures. With a population of over 8 million inhabitants, Moscow, the capital of Russia, is listed as the largest European city out of a total of 500 cities in Europe, according to studies; London, the capital of the United Kingdom, is second, followed by St. Petersburg, Berlin, Madrid and Rome.

The historical development of Germany and Italy has led to the development of a large number of important but smaller cities. The percentage of people living in larger cities is therefore relatively low. In Germany, about $26 \%$ of the population live in these big cities, while only $21 \%$ of Italians live in cities with populations of over 150,000 people. In Poland, a country where the rural population is still a major force, about $24 \%$ of people live in large cities. With more than seven million inhabitants, London, the capital of the United Kingdom, accounts for almost $12 \%$ of the country's population (about $51 \%$ of the British live in cities with over 150,000 inhabitants). Russia boasts 116 cities with over 150,000 inhabitants, while in Germany 51 cities enjoy the status of Großstadt. France is a big country with relatively few big cities, so that only 16 French cities accommodate over 150,000 people. [54]

A report by Eurostat highlights that the metropolitan areas of the EU generates about 70\% of GDP, records the fastest growth rates of the population, generates a significant share of the new jobs and concentrates a significant share of tertiary education graduates. Thus, the larger the metropolitan areas, the more they stimulate the development of stronger economies, using much larger pools to attract the workforce and make possible more efficient incentives for investments.

In the EU, real GDP growth has seen considerable variations both over time and between the Member States. After a reduction in 2009 in all EU Member States, except Poland, the economic growth returned in 2010 to 22 EU Member States, a trend that continued in 2011, when there was a growth of GDP- in 24 EU member states. In 2012, however, this evolution reversed, as 13 of the Member States reported economic growth, while in 2013 their number increased to 17 and in 2014 to 23.

The highest growth rates in 2014 were recorded in Ireland (4.8\%), Hungary (3.6\%), Malta (3.5\%) and Poland (3.4\%). In 2014, Spain's growth (1.4\%) was slightly above the EU-28 average (1.3\%), this being the first annual growth in the Spanish economy registered after 2008. While in 2014, GDP growth in Portugal $(0.9 \%)$ and Greece $(0.8 \%)$ was below the EU-28 average, for Portugal this was the first annual growth recorded after 2010, and for Greece the first after 2007. In 2014, the Cypriot, Italian and Finnish economies registered a decrease for the third consecutive year, while in Croatia it was the sixth consecutive year of fall of the real GDP: in three of these four Member States, in 2014, the decrease was relatively small, except for Cyprus, where the GDP decreased by 2.3\%. The effects of the economic and financial crisis have reduced the overall performance of the economies of the EU member states over the last ten years. The average annual growth rates for the US-28 and the euro area (ZE-19) in the period 2004-2014 were $0.9 \%$ and $0.7 \%$ respectively. The highest growth, measured with the help of this indicator, was recorded in Poland (average growth of 3.9\% per year) and Slovakia (3.8\% per year), followed by Romania (2.7\%), Bulgaria, Latvia and Malta (each 2.5\% each). On the other hand, the real GDP in 2004-2014 has declined globally in Greece, Italy and Portugal. [56] [67]

In the metropolitan areas, the distribution of GDP expressed in the market prices during the period 2012-2013 shows a high share in the metropolitan areas with a population of over 1 million inhabitants and in the non-metropolitan areas which concentrates most of the economic activities, but also the job opportunities.

The demographic changes in the EU will likely be of considerable importance in the coming decades, as the vast majority of scenarios regarding future population trends suggest that the EU will continue to age due to low fertility levels and prolonged longevity.

The population of the EU-28 increased in 2015 with 1.8 million people. Population growth was unevenly distributed among the EU member states: a total of 17 Member States registered an increase of their population, while the population decreased in the other 11 Member States. Luxembourg, Austria, Germany, Malta and Sweden recorded the highest population growth rates in 2015, with an increase of over 10.0 per 1,000 people, almost three times more than the EU-28 average of 3, 5 to 1,000 people. Of the five member states of the U.E. with the highest rates of population growth, the fastest population growth was recorded in Luxembourg, with an increase of 23.3 per 1,000 people, while the largest relative decreases in population were reported by Lithuania $(-11.3$ per 1,000 people), Latvia $(-8.7)$ and Croatia $(-8.2)$. [57] 


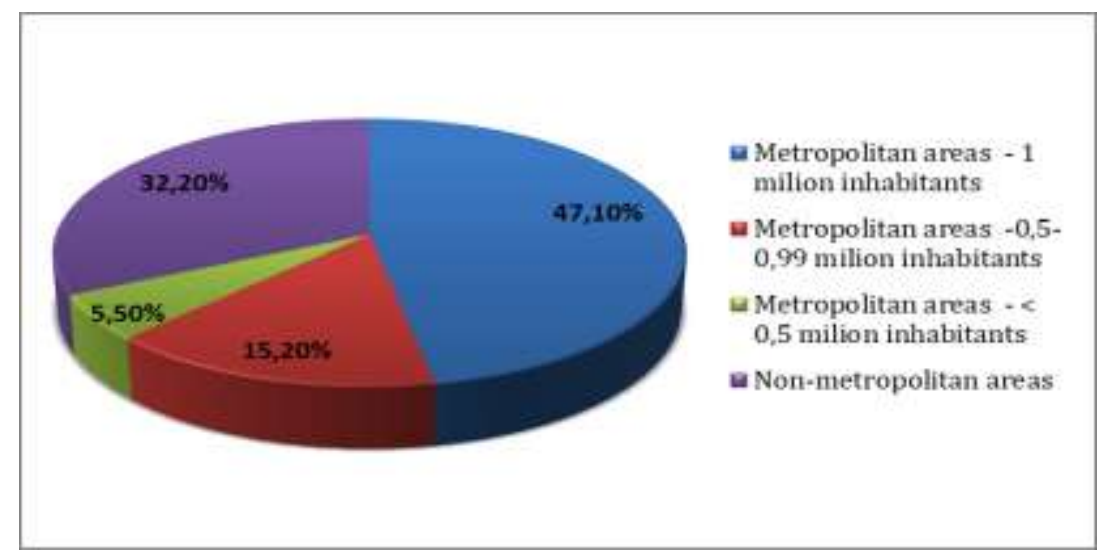

\section{Chart no. 1. Distribution of metropolitan areas according to GDP expressed in market prices (2012-2013) \\ Source: www.eurostat.ro}

The social and economic consequences associated with the aging of the population can have profound implications throughout Europe, both nationally and regionally. For example, the low fertility rate will lead to a reduction in the number of students in education, there will be fewer working people to support the rest of the population and a larger proportion of the elderly (some of whom will need additional infrastructure, healthcare services and adapted housing). These structural demographic changes could impact on the ability of governments to increase tax revenues, balance their finances, or provide adequate pensions and health care services. [67]

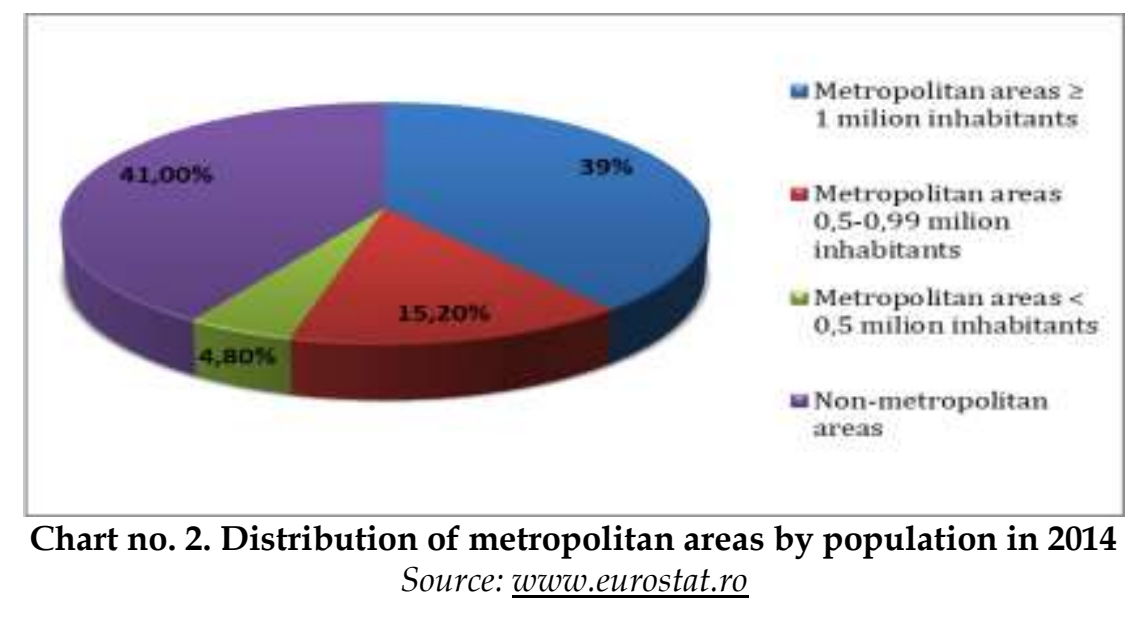

Most regions in the EU have registered a progressive increase in the relative weight of their elderly population, as a result of the significant and continuous increase of life expectancy and the retirement of the boom generation,the generation after the Second World War. The regions with the highest share of the elderly are often identified as rural areas, relatively remote and sparsely populated, where a small part of the elderly can be, at least in part, linked to the lack of employment opportunities and education, urging younger generations to leave in search of work or continue their studies.

The demographic structures within the individual member states of the EU often have irregular patterns, which can have an impact on regional competitiveness and cohesion. Sometimes these differences are quite obvious, such as Germany (where there is often a contrast between the east and west regions), France (northeast and southwest), Italy (north and south) and Turkey (east and west). These differences can be attributed to a wide range of factors, such as: climate, landscape, historical, political, social and economic developments.

Since 2015, 508.5 million inhabitants lived in the EU-28. Across the EU-28, younger people (0-19 years) represented $20.9 \%$ of the total population on January 1, 2015, while the population aged 20-64 represented three fifths of the total (60.2\%). whereas, $18.9 \%$ of the population, the elderly, is 65 and above. Looking more closely at the working age group, $12.2 \%$ of the population was $20-34$ years old, $28.6 \%$ were 35 54 years old, and $12.8 \%$ of the age group were $55-64$ years old. 


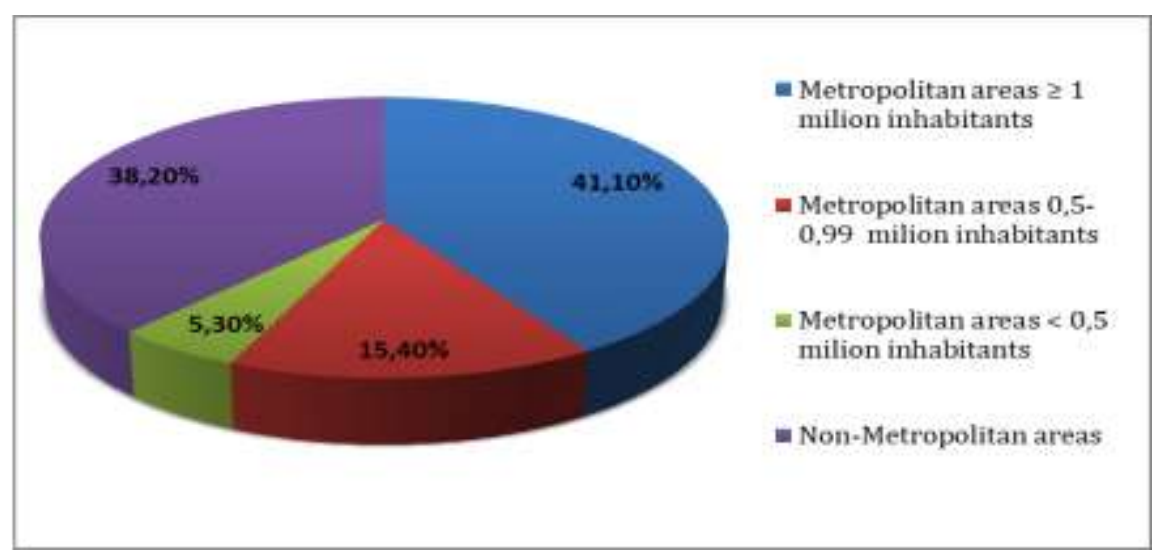

Chart no. 3. Distribution of metropolitan areas by occupation

(2012-2013)

Source: www.eurostat.ro

Also, the migration crisis will lead to reconsiderations and adjustments of immigration policies in the developed European countries and possibly to resettlements in the development strategies. Governments are expected to undertake programs and measures to increase the participation in economic activities of the inactive national population, together with measures already taken to increase the standard retirement age limit and the years of service for full retirement. Reserves are important if we look at the employment rates of the working age population (15-64 years): values of 72-74\% in Germany, the United Kingdom, Sweden, the Netherlands, Denmark and values below 65\% in most of the the other countries (61\% in Romania). [67]On the other hand, in February this year the unemployment rate increased to $10.2 \%$ in France, $11.7 \%$ in Italy, $12.3 \%$ in Portugal, $20.4 \%$ in Spain, 24\% in Greece, at the level of the European Union being 21.7 million unemployed.

Immigration has become a major component of the development and maintenance of high growth in the developed countries of the European Union in recent decades. The total net migration in France, Germany, Italy and the United Kingdom in the period 1990-2014 reached 15 million people. With regard to net migration, meaning the difference between immigration and emigration, one can easily see a considerably higher level of immigration than the net migration, while in the four countries there is, during the same period, a significant emigration. The natural growth was only 5 million people.

If we add the data for Spain, a country with a remarkable economic expansion before the economic and financial crisis and a massive immigration, the net migration reaches 21 million, and the natural growth only 6 million. It is expected that the great migration crisis of 2015, with effects not yet well known on the economic, social and cultural level, will lead to the installation of a period of expectation and reconsideration on immigration (size and origin), but also to the reconsideration of employment policies. of the labor force. The data from the last decades on the spectacular growth of the economies of the developed European countries and their size in relation to the national labor force and the demographic state of the country are arguments for the indispensability of immigration and in the future. A look at the prospects of population decline in our country, in a complex and deteriorating European demographic context, completes the European image.

In 2014, in the EU-28 there were 122 million people who were at risk of poverty or social exclusion, which is equivalent to $24.4 \%$ of the population. [56] [67] The objective of the EU is to take 20 million people out from poverty and social exclusion by 2020. In 2014, 34 million people lived in EU-28 cities and were facing such problems, while the corresponding figures for those living in cities and suburbs (24.2 million) and rural areas (27.9 million) were somewhat smaller. In relative terms, the highest risk of poverty or social exclusion within the EU-28 was registered among people living in rural areas (27.1\%), some 2.8 percentage higher than the quota for people living in cities (24.3\%) and 4.8 points higher than those living in cities and suburbs $(22.3 \%)$.

In 2014, there were large disparities between the EU member states in areas where the risk of poverty has been concentrated. The highest rate of poverty risk in 2009 in the Western Member States (Belgium, Denmark, Germany, the Netherlands, Austria and Austria United Kingdom) was among those living in cities. The percentage of the population living in Austrian cities who were at risk of poverty was 2 times higher than the percentage of people living in rural areas, while the same ratio in Belgium was 1.6: 1. France, Cyprus and Luxembourg were the only Member States that reported the highest rate of poverty risk among those living in cities and suburbs, while the highest rate of poverty risk in the EU. 19 Member States remained among the people living in rural areas. The risk of poverty among people living in rural areas of Romania and Hungary was three times higher than the corresponding rate recorded among those living in cities, while in countries 
such as Malta, Bulgaria, Poland and Lithuania, people living in rural areas were more than twice as likely as those living in cities to be at risk of poverty. [56]

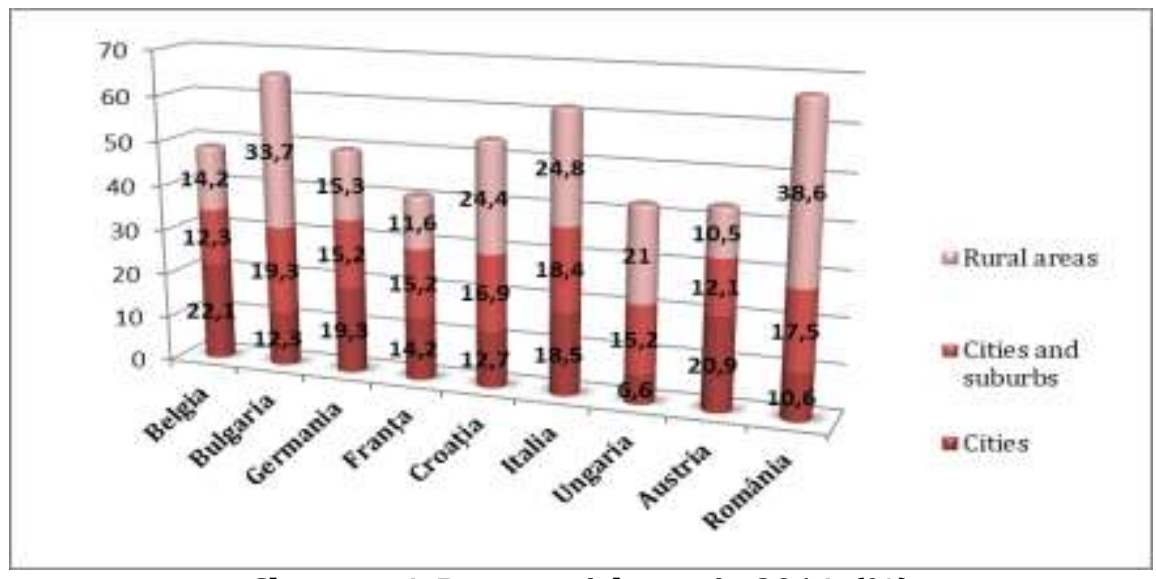

Chart no. 4. Poverty risk rate in $2014(\%)$ Source: www.eurostat.ro

The EU, through its sustainable development strategy, seeks to identify and develop actions that enable member countries to continuously improve the quality of life for both current and future generations, by creating sustainable communities that are capable of effectively managing and utilizing resources, while ecological promotion and the potential for social innovation of the economy ensure prosperity, environmental protection and social cohesion.

An analysis in terms of the degree of urbanization shows that people living in the cities of Croatia, Portugal, Estonia, Bulgaria, Greece and Slovenia generally had a higher overall level of life satisfaction than their compatriots who live in cities and suburbs or in rural areas. At the opposite pole in Denmark, Ireland, Cyprus, Luxembourg and the United Kingdom, the number of people living in rural areas had the highest levels of overall life satisfaction.

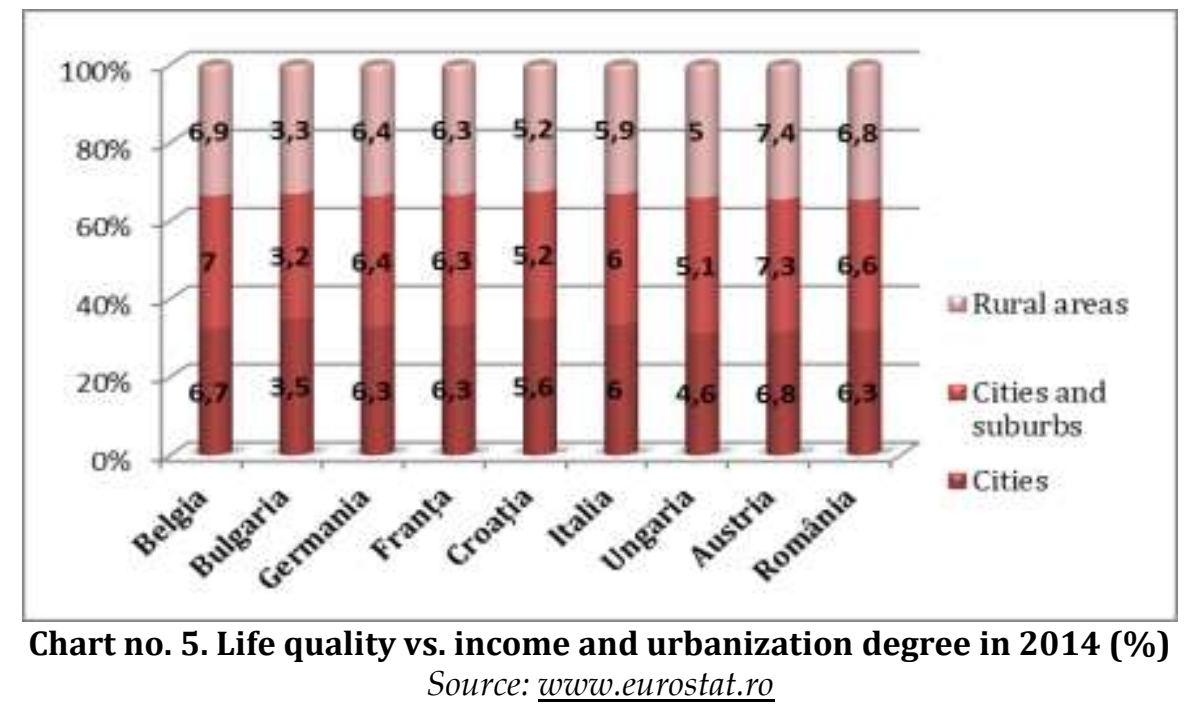

In terms of the number of people living in cities, the difference in the overall life satisfaction between those with the highest incomes and those with the lowest incomes was 1.0 or less in Denmark, Luxembourg, Sweden, Finland and The Netherlands, all characterized by a relatively high level of spending on social policies and cohesion. On the other hand, there were greater differences in the overall levels of life satisfaction between those on both sides of the income distribution in Bulgaria and Hungary (the level of satisfaction recorded by those with high incomes is 2.5 times higher than that of low-income people), Estonia and Lithuania $(2,2)$ and Croatia $(2,1)$, where income differences seemed to have a greater impact on overall life satisfaction. [56]

In most EU member states, the level of overall life satisfaction among single people living in cities was higher than the national average recorded for those living alone; this was, in particular, the case of Bulgaria and Croatia (a difference of 0.6), as well as of Romania, Slovakia and Hungary (0.3). These figures could suggest that some people living in cities have taken advantage of the wide range of opportunities that exist in many European cities for education, work, entertainment, culture or social relations, while those living alone 
in the other two types of areas may feel more isolated and disconnected from life. There were six Member States where the overall level of life satisfaction of single people living in cities was lower than for the population living alone (although their differences were not very large): Denmark, Sweden, Ireland, Belgium, Cyprus (a difference of 0.1) and the United Kingdom (0.2).

Table 1. The main indicators for the capitals of the metropolitan areas in 2014

\begin{tabular}{|c|c|c|c|c|c|c|}
\hline \multirow{2}{*}{ Capitals } & \multicolumn{2}{|c|}{ Population } & \multicolumn{2}{|c|}{$\begin{array}{l}\text { Employment - persons aged 15- } \\
64\end{array}$} & \multicolumn{2}{|c|}{ GDP } \\
\hline & $\begin{array}{l}\text { milion } \\
\text { inhabitants }\end{array}$ & $\begin{array}{c}\% \text { share of } \\
\text { national/total }\end{array}$ & milion & $\begin{array}{c}\% \text { share of } \\
\text { national/total }\end{array}$ & milion EUR & $\begin{array}{l}\% \text { share of } \\
\text { national/total }\end{array}$ \\
\hline Brussels & 2,97 & 26,5 & 1,19 & 26,5 & 135.129 & 34,4 \\
\hline Sofia & 1,68 & 23,2 & 0,78 & 26,6 & 17.862 & 42,8 \\
\hline Berlin & 5,01 & 6,2 & 2,39 & 6,1 & 146.191 & 5,3 \\
\hline Paris & 12,01 & 18,2 & - & - & 623.189 & 29,9 \\
\hline Zagreb & 1,12 & 26,3 & 0,54 & 35,1 & 17.147 & 39,0 \\
\hline Roma & 4,32 & 7,1 & 1,73 & 7,9 & 153.748 & 9,5 \\
\hline Budapesta & 2,97 & 30,0 & 1,30 & 31,9 & 47.288 & 100,0 \\
\hline Viena & 2,68 & 31,5 & 1,21 & 29,9 & 110.704 & 34,9 \\
\hline București & 2,28 & 11,4 & 1,06 & 12,8 & 36.332 & 27,2 \\
\hline
\end{tabular}

From the analysis of the indicators presented in the table first three places are occupied by cities such as Paris, Berlin and Rome, finding both high indices of the number of inhabitants, as well as an active labor force occupied, as well as high levels of GDP. Of note, in this context are Brussels and Vienna, which although not being registered as large urban agglomerations, record high levels of GDP, 135.129 and 110.704 million euros.

A large and complex phenomenon, extremely visible in the last period of time, is represented by suburbanization. [13] Suburbanization can determine:

$>$ modification of the functional structure of these settlements;

$>$ spatial expansion of the city / metropolis;

$>$ expanding the sphere of influence of the city / metropolis;

$>$ the increase in the number of inhabitants in the localities nearby or in the peripheral neighborhoods, etc.

The causes of suburbanization are diverse but at European level we can specify:

$>$ the increase of metropolises through the contribution of population from rural and agricultural areas or from de-industrialized areas;

$>$ the immigrant inflows;

$>$ establishing the residence of financially enriched social categories in the proximity of the city;

$>$ an economic development of the localities in the metropolitan area, etc.

The most spectacular suburban population growth exists in the localities on the outskirts of Madrid, an increase generated by the migration phenomenon. Metropolitan Berlin is surrounded by three rings, the first reflecting population growth, the second shows a slow population decline and the third ring representing the fastest population decline. In Poland there is a multi-polar suburbanization process, in the sense that there are several cities that have created such "suburbanization rings". The phenomenon can be accounted for by the concentration of capital and services in these cities, in the context of lower economic importance of traditional industrial branches. The population in the city decreases, while in the proximal localities it increases. The latest representative case is the "Balkan type" of the southwestern states of the peninsula: Montenegro, Kosovo, Albania and Macedonia. Their characteristic is the disproportionate increase in the number of inhabitants in the capital compared to the rest of the territory and there are no "clear suburbanization rings".

\section{Conclusions}

Following implementation of cohesion policy and the results of intergovernmental cooperation in the field of territorial planning and development, it has become increasingly evident that territory must become a main element in process of elaborating and implementing European policies.

Competitiveness and well-being of Europe's metropolitan areas are extremely important for achieving the objectives of European Convention on territorial cohesion, Lisbon and Goteborg Strategies, programs which focused on competitiveness and sustainable economic development, of European Space Development Perspective (ESDP), which aim at essential actions to improve the urban balance and the eighth Cohesion Report focused on economic and social cohesion. 
Competitiveness demands an inclusive approach to urban issues from an economic, social, environmental and responsible point of view, and competitiveness and urban cohesion can be sustained by creating efficient tools for making strategic decisions and implementing actions within functional urban areas (according to ESPON reports) especially those with metropolitan characteristics. Thus, the recognition and definition of european metropolitan areas is an essential requirement for them to be able to contribute to the implementation of European policies.

\section{References}

1. Balazs, F., Minea, E., Ghiltan, C., Stănică, V., Descentralizare. Dezvoltare urbană, suport de curs, Cluj-Napoca, 2010;

2. Barca, F., An Agenda for a Reformed Cohesion Policy: A Place-based Approach to Meeting European Union Challenges and Expectations, Bruxelles, www.ec.europa.eu;

3. Barna, B., Politica regională și dezvoltarea teritoriului, Fundația Diaspora, Timișoara, 2003;

4. Bartle, J., Swayze, R., Interlocal cooperation in Nebraska: prepared for the Nebraska mandates management initiative, 1997;

5. Dabu, R., coord., Modele de dezvoltare comunitară adaptate comunităților rurale din România, București, 2009;

6. Duhr, S., Colomb, C., Nadin, V., European Spatial Planning and Territorial Cooperation, London and New York: Routledge, Taylor \& Francis Group, 2010;

7. Dumitrică, C.D., Zona metropolitană ca răspuns reflex la guvernarea multinivel și deciziile publice naționale derivate, Rev. Economie teoretică și aplicată, 2013;

8. Erdeli, G., Simion, G., Local descentralization and extended suburbanization: a geographical approach of the metropolisation process in Roumania, Ed. Societății de Geografie, București, 1999;

9. Garofoli, G., Local development in Europe, theoretical models and international comparisons, European Urban and Regional Studies, 2002;

10. Hearley\&Baker, European Cities Monitor, 2002;

11. Lecarte, J., Coeziune economică, socială și teritorială, octombrie 2016, www.europarl.europa.eu;

12. Matei, R.M., Crearea polilor de competitivitate economică, un model sustenabil pentru obținerea avantajului competitiv, Rev. Economie teoretică și aplicată, 2013;

13. Nicolae, I., Suburbanismul, ca fenomen geografic în România, 2002, Ed. Meronia, București;

14. Pacesila, M., Regionalizarea în statele U.E., Rev. Administrație și Management Public, 2004;

15. Petrescu, C., Constantin, A., Parteneriat și dezvoltare locală, Rev. Sociologie Românească, vol. VIII, 2010;

16. Phillips, R., Pittman, $R$, An Introduction to Community Development, Taylor\&Francis, 2008;

17. Pike, A. et al., Local and regional development, London, 2006;

18. Popescu, I., Dimensiunea metropolitană a Europei: de la orașe la regiun urbane, ASE, București, 2005;

19. Profiroiu M., Descentralizarea în România, Rev. Administrație și Management Public, 2014;

20. Pupăzău, C., Forme de cooperare în cadrul autorităților administrației publice locale, Analele Univ. "Al.I.Cuza", Iași, 2007;

21. Săgeată, R., Zonele metropolitane în România, Institutul de Geografie, București, 2015;

22. Sârbovan, C., Periurbanizarea, de la spațiu polarizat la spațiu integrat, Noosfera, 1996;

23. Sârbu, C., Arii metropolitane în România, premise privind investiția în teritoriul național și european, Universitatea "Ion Mincu", București, 2012;

24. Stănescu, I., Procesul de regionalizare-descentralizare, o analiză pe trei dimensiuni, Rev. Calitatea vieții, 2014;

25. Trașcă, D., Aceleanu, M., Sahlian, D., Eficiența în plan teritorial a politicii de coeziune în România, Rev. Economie teoretică și aplicată, vol. XX, 2013;

26. Vasquez Barquero, A., Endogenous development. Networking, innovation, institutions and cities, Madrid, 2003,

27. Weber, M.,Economy and society, University of California Press, 1978;

28. Abordarea Leader, Comisia Europeană, 2006;

29. Acțiuni de dezvoltare locală sub responsabilitatea comunității, noiembrie 2012, Comisia Europeană;

30. Agenda Teritorială a Uniunii Europene 2020, Comisia Europeană, 2011;

31. Analiza Comparativă a Dezvoltării Zonelor Metropolitane din Europa, CDCAS, București, 2007;

32. Banca Mondială: România metropolitană și problemele ei. Deficiențele din "polii de creștere" împiedică dezvoltarea întregii ţări, www.worldbank.org;

33. CEC (2012a), European Spatial Development Perspective, Wikipedia, the Free Encyclopaedia;

34. CEC (2011b), Territorial Agenda of the European Union 2020: Towards an Inclusive, Smart and Sustainable Europe of Diverse Regions, Hungary: Commission of the European Communities;

35. CEC (2010b), Europe 2020: A Strategy for Smart, Sustainable and Inclusive Growth, Brussels: Commission of the European Communities

36. CEMR reponse to the cohesion policy 2014-2020, www.urban-intergroup.eu;

37. Cohesion Policy 2014-2020, Towards a newpartnership and territorial approach, octombrie 2013, Council of European Municipalities and Regions, www.ccre.org;

38. Cohesion policy support for local development: best practice and future policy options, 2010, www.ec.europa.eu;

39. Comisia Europeană, www.enrd.ec.europa.eu;

40. Community Led Local Development ECO/366, septembrie 2014, Bruxelles, European Economic and Social Committe;

41. Dezvoltarea locală plasată sub responsabilitatea comunității, Politica de coeziune 2014-2020, www.ec.europa.eu;

42. Dezvoltarea metropolitană, vitală pentru economia României, Cicovschi, A., www.curierulnational.ro;

43. Dimensiunea teritorială 2014-2020, www.mdrap.ro;

44. ESPON, www.espon.eu;

45. Implicațile Sociale și Economice ale Procesului European de Metropolizare, CDCAS București, 2007;

46. Investiții pentru locuri de muncă și creștere. Promovarea dezvoltării și a bunei guvernanțe în regiunile și orașele U.E., Raportul al VI-lea de coerziune economică, socială și teritorială, iulie 2014, Comisia Europeană;

47. Local development in cohesion policy CEMR, Bruxelles, 2010

48. Obiectivele Europa 2020, Comisia Europeană, www.ec.europa.eu;

49. Orientări privind dezvoltarea locală pasată sub responsabilitatea comunitătii pentru actorii locali, august 2014, Comisia Europeană

50. Raport privind polii de creștere, Banca Mondială, 2013;

51. Raport strategic național 2012 privind implementarea Fondurilor structurale și de coeziune, februarie 2013;

52. Raport al Comisiei către Parlamentul European și Consiliu - Al optulea raport intermediar privind coeziunea economică, socială și teritorială: Dimensiunea regională și urbană a crizei [COM(2013) 463 final, 26.6.2013] 
53. Strategia de dezvoltare teritorială a României, România policentrică 2035, Coeziune și competitivitate teritorială, dezvoltare și șanse egale pentru oameni, februarie 2015, www.sdtr.ro;

54. Tann vom Hove, City mayors, www.citymayors.com;

55. Transformarea orașelor mari din România în motoare ale creșterii economice, www.worldbank.org;

56. Urban Europe, statistics on cities, towns and suburbs, 2016, www.eurostat.eu;

57. Zonele metropolitane/regiuni urbane: Strategia Europa 2020, Comitetul Economic și Social European, Bruxelles, 2011.

58. Zonele metropolitane - avantaje și dezavantaje, februarie 2006, www.romanialibera.ro.

59. www.ccre.org

60. www.cedd.ro;

61. www.citymayors.com

62. www.curierulnational.ro

63. www.ec.europa.eu/agriculture/rur/leaderplus;

64. www.enrd.ec.europa.eu

65. www.europarl.europa.eu

66. www.espon.eu

67. www.eurostat.eu;

68. www.madr.ro;

69. www.mdrap.ro

70. www.romanialibera.ro

71. www.sdtr.ro

72. www.urban-intergroup.eu

73. www.worldbank.org 